\title{
Beyond museums: religion in other visitor attractions
}

\section{Crispin Paine}

\section{(2) OpenEdition \\ 1 Journals}

Electronic version

URL: http://journals.openedition.org/iss/1753

DOI: $10.4000 /$ iss. 1753

ISSN: 2306-4161

Publisher

ICOM - International Council of Museums

\section{Printed version}

Date of publication: 12 October 2019

Number of pages: 157-169

ISBN: 978-92-9012-467-2

ISSN: 2309-1290

\section{Electronic reference}

Crispin Paine, "Beyond museums: religion in other visitor attractions », ICOFOM Study Series [Online], 47(1-2) | 2019, Online since 12 October 2019, connection on 24 October 2019. URL : http:// journals.openedition.org/iss/1753; DOI : 10.4000/iss. 1753 


\title{
Beyond \\ museums: \\ religion in \\ other visitor \\ attractions
}

\author{
Crispin Paine \\ United Kingdom
}

Abstract

Museums offer three very different things: public entertainment, public education and scholarly research. In all three areas museums have, over the past generation, transformed the ways they understand, use and present religion. This transformation in museums worldwide has forged new correspondences with other kinds of visitor attraction, like places of worship, libraries, pilgrimage centres, theme parks or zoos. The barriers that once separated museums from other institutions that welcome visitors have broken down, perhaps especially in the field of religion. In this short note I shall look briefly at some of the approaches museums have come to share with other attractions that present religion to visitors, and at some of the motives they share.

Key words: theme park, museum, shrine, visitor, culture park, religion park, treasury 


\section{RESUMÉ}

Les musées offrent trois choses très différentes: le divertissement public, l'éducation publique et la recherche scientifique. Dans les trois domaines, les musées ont, au cours de la dernière génération, transformé leur façon de comprendre, d'utiliser et de présenter la religion. Cette transformation dans les musées du monde entier a forgé de nouvelles correspondances avec d'autres attractions publiques, tels que des lieux de culte, des bibliothèques, des centres de pèlerinage, des parcs à thème ou des zoos. Les barrières qui séparaient autrefois les musées des autres institutions accueillant les visiteurs se sont effondrées, peut-être surtout dans le domaine religieux. Dans ce court article, j'examinerai quelques-unes des approches que les musées sont venus partager avec d'autres attractions qui présentent la religion aux visiteurs, ainsi que les motivations qu'ils partagent.

Mots clés : parc à thème, musée, temple, visiteur, parc culturel, parc religieux, trésor

\section{Introduction}

This brief paper draws attention to the ways in which museums overlap with, and sometimes merge with, other types of visitor attraction that also present and interpret religion. Museums have for well over two centuries been conscious of themselves as a distinct kind of public service, which uses carefully-chosen and well-managed and researched collections of objects to interest and educate their visitors, today and in future generations. They especially boast their role in guarding 'the Real Thing', and are sometimes almost scornful of institutions that tell history stories without that precious resource. The awe the viewer can sense in front of a meaningful original object has been given the splendid name 'magical contagion', a kind of sympathetic magic (Evans and Poling 2002, 73)

But museums share a great many features with other kinds of visitor attraction, an affinity that is increasing as society looks more and more to museums to attract and entertain people of all sorts. I want here to draw attention to some of the correspondences between museums and other institutions in the specific field of religion. As we shall see, there is an extraordinary variety of 'other institutions' with which museums can overlap when they talk about religion; they range from the most ancient centres of pilgrimage to the most modern theme parks.

\footnotetext{
I. 'Authenticity' has been the subject of much scholarly consideration and debate over the past generation, including in the fields of heritage and religious practice. Its role in different kinds of modern visitor attraction deserves its increasing attention (Carlà-Uhink et al., in press; Paine 2org, chapter 7 ).
} 
Moreover, museums have (as this volume clearly shows) developed very much more interest in religion of recent years. Fifteen years ago there were only a handful of general books about religion in museums; today there is a shelf-full, and we shall soon need another shelf. Fifteen years ago the great majority of museums housed religious objects, but they almost always regarded those objects as works of art or as illustrations of culture, and few exhibitions addressed questions that could be seen as 'religious'. Today many museums take very seriously the religious meaning of the objects they care for. They treat them in a way that reflects that concern, and accept a responsibility to present and explain their religious context and message to visitors (Paine, 2013; Buggeln, Paine \& Plate, 2017; Buggeln \& Franco, 2018). Sometimes this results in the distinction between museum and temple or church almost breaking down, and we shall see examples of museums that are also shrines, and shrines that are nearly museums.

This sea-change in the way museums regard religion has of course raised problems. The most obvious is the controversy that so often swirls around religion. Secularists and members of other faiths sometimes complain that a museum is promoting a particular faith, or even betraying its lay, scientific, tradition. Another problem is the demand made by some faith-groups that 'their' objects be treated with respect. Quite what this 'respect' means is not at all clear; philosophers who have discussed respect have almost all seen it as something owed to people, not to objects. A third problem arises in those parts of the world that have seen the collapse of religious faith and practice in recent decades; there many visitors have no background in faith, and find it hard to understand or empathise with the religious meaning the museum is trying to explain.

Yet the revolution - I suggest that is not too strong a word - that has overtaken religion in museums is very welcome and long overdue. Museums' mission is to help as many people as possible to understand the world, and understanding religion is a key part of that. And museums are not alone; museums share with many other visitor attractions their role in what the religious studies pioneer Ninian Smart called 'The Long Search'.

\section{Telling the story: mission}

The most obvious kind of 'religious' visitor attraction is one that sets out to tell the story of a particular faith group, and thereby to reinforce the faith of its members, and to attract the interest of others. There are countless museums of this sort worldwide, though perhaps Protestant Christian museums are the most common; in London one thinks at once of the Museum of Methodism and the Salvation Army Museum, but also of the Jewish Museum. The rarest are perhaps museums of Islam - as distinct from museums of Islamic Art ${ }^{1}$.

I. Even the few museums attached to mosques (like the Sultan Qaboos Grand Mosque in Muscat) or 
Other types of visitor attraction presenting Islam are also rare; one of the few is Prophet Mohammed Cinematic City near Qom, Iran. This is a reconstruction of Mecca at the time of Mohammed; retained when director Majid Majidi had finished filming Muhammed: the Messenger of God, it has now become a significant religious attraction in its own right.

Krishna Lila Theme Park, under development on the outskirts of Bangalore, India, is another visitor attraction whose principal motive is mission. It is a project of ISKCON Bangalore and aims to tell the story and the message of the Lord Krishna. As the website puts it:

Today, our children's minds are obsessed with Superman, Spiderman and such other characters coming from the West. Hence the project aims to impress upon the younger generation the glorious pastimes of our Vedic heroes like Krishna, Rama and Hanuman and instill in their minds the deep values they represent. ${ }^{1}$

The park will include a I37 metre tower with temples at top and bottom and an enormous 'Science and Spirituality Exposition' between. Other attractions include an Animation Theatre, a Bhagavad Gita exhibition, a 'Govardhan Hill Experience' where the mountain rises to let visitors in, a themed water fountain, a water-ride through the Adventures of Krishna, and a ${ }_{4} \mathrm{D}$ Theatre, as well as a Kids Zone, gardens etc. The park aims to attract 20,0oo visitors a day.

Probably the best-known of all visitor attractions that set out to present a particular faith is Holy Land Experience in Orlando, Florida, USA. HLE was originally founded in 1997 by an Evangelical Christian group who felt a special mission to both convert Jews, and help Christians understand Judaism. It describes itself as 'a living, biblical museum and park that brings the world of the Bible to life!' and it attracts some quarter of a million visitors a year.

Not only does Orlando Holy Land Experience have the same purpose as many religion museums, it also actually incorporates a conventional museum: The Scriptorium. This $\$ 9 \mathrm{~m}$ museum houses the collection of multi-millionaire investment banker and passionate Evangelical Christian Robert van Kampen. It includes I, ooo cuneiform tablets, 5, ooo papyrus fragments, key Coptic, Early Greek and Syriac manuscripts, a large collection of European medieval manuscripts, and over thirty Latin Bibles printed before I5OI.

based on collections of Qur'ans (such as the Sheikh Faisal bin Qassim Al Thani Museum in Qatar) focus on the culture rather than the faith and practice of Islam. That story is largely left to major secular museums, like the excellent new Islam gallery in the British Museum.

I. https://www.iskconbangalore.org/krishna-lila-park (Accessed 24.I.20I9). 
Another religious theme park that houses a conventional museum is Akshardham Gujerat. This huge temple-cum-theme park was opened in 1992 in Gandhinagar, India, by the BAPS branch of the Swaminarayan Hindu sect. Swaminarayan (I78I-1830) was a Vishnavite Hindu ascetic and reformer regarded as an incarnation of God, whose successors built a sect that today claims twenty million followers. His great temple is surrounded by lawns, a large cloister, and a series of exhibitions, the chief of which is a walk-through series of partly-animatronic dioramas depicting his life. The basement of the temple contains a museum displaying personal possessions of Swaminarayan. A panel informs one:

\begin{abstract}
Here, the objects have been scientifically treated and authentically displayed to provide future generations with a historical and spiritual testimony to the Lord. These holy relics are priceless because of the immense spiritual power they carry within them lies the presence of Lord Swaminarayan that blesses one and all with good fortune and inner peace [sic].
\end{abstract}

\title{
99
}

Here we find museum and shrine merging. There are a great many other examples of this merging, in many parts of the world. At the Twenty-Six Martyrs Museum and Monument at Nagasaki in Japan, pilgrims can see personal and significant possessions of the twenty Japanese Christians and six foreign missionaries who were crucified here in I597. Pope St. John Paul II visited in 1981. Even more clearly a shrine as well as a museum is the Knights of Columbus Museum in New Haven, Connecticut, USA. Here the museum galleries telling the story of the Order are interrupted by a gallery in which are displayed objects belonging to the Order's founder, The Venerable Father Michael J. McGivney. They feel much more like relics displayed in a shrine than objects displayed in a museum.

Such shrine/museums may be regarded by some as 'sacred places', which reminds us of the analogy between the 'sacred' as the term is used in a religious context, and the way in which museums treat their objects as 'special'. I have argued elsewhere (Рaine 2ог3) that 'sacred' is simply a special kind of special and that there is a striking analogy between the specialness of the museum object and the specialness of the religious artefact. They come together in the religious object in a museum. There is of course a huge literature on this topic, from both a museological perspective and from (especially) a religious studies perspective. Similarly theme parks are sometimes seen as sacred places (Paine, 2019, chapter 6), and so sometimes are museums, as many of the contributions to this volume attest. Here in shrine/museums is another area of overlap between museums and religion parks. 


\section{Heritage sites, secular perspectives}

But by no means all attractions that tell a religious story do so in a spirit of mission. There are a great many historic sites, theme parks and museums that are dedicated to interpreting a religious story from an entirely secular perspective. One museum example among very many is the Panacea Museum in Bedford, England. This group of houses in a prosperous area of the town was the home through most of the twentieth century of a group of women who believed that their leader was the Daughter of God, and who kept a house ready for Christ to occupy when He returned (Shaw, 20II). Today it is a museum dedicated to telling the story not only of the Panacea Society and its extraordinary missionary efforts, but of the English millenarian tradition in which it stood. The Trustees who run the museum may have great interest in and considerable sympathy for the Society, but they are not believers. There are many museums and historic sites like that, and as tourism grows and appreciation of the world's built heritage grows, more and more historic places will need to find a balance between presenting their religious character and their architectural, artistic and historic appeal (Mairesse, 2018).

There are a great many museums that, like the Panacea Museum, have grown out of a heritage site or are still mainly a heritage site, and many of these sites were once religious in character. Typical are ruined monasteries, ancient temples and the like. Though these are often counted as 'religious museums', many of them seem mainly to focus on architectural history, and to make disappointingly little effort to explain the religious impulses, beliefs and practices that once gave them their purpose. It will be interesting to see whether the wider adoption of Augmented Reality and other new interpretation techniques encourage their managers to try harder to explain their religious meaning and former function.

\section{Cultural Theme Parks}

Museums overlap, too, with attractions that present and interpret religion not so much for its own sake as for its role as a part of culture. There are many thousands of theme parks, in many parts of the world, that take as their theme either the 'traditional' culture of their own region, or the culture of foreign places - the 'exotic other'. Such culture parks are particularly popular in east Asia - Joy Hendry's 2000 study of culture parks in Japan is a very helpful introduction. Many such parks, of course, concentrate on attracting visitors and make little attempt at accuracy or truth-telling, instead presenting as exotic an image as possible, and one that plays to their visitors' preconceptions and prejudices. Others, though, are very close to open-air museums, and take seriously their responsibilities as educators.

Little World: Museum of Mankind at Inuyama in Japan is essentially an ethnographic museum presenting the world's cultures through open-air exhibits as well as indoor displays; I20 hectares contain thirty-three buildings from twenty-two countries, plus five large exhibition halls. One of these is the Hall 
of Values, which presents world religions in conventional museum showcases. Outside, many of the 'countries' have religious buildings, often well fitted out; Germany has a fine baroque church, Taiwan a shrine, and Indonesia a temple. Most culture parks, at whichever end of the educational spectrum they stand, include religion in some way, usually through reconstructed or replicated temples or churches. Indonesia's Taman Mini has a mosque, a Buddhist temple, a Hindu temple, a Confucian temple and Catholic and Protestant churches, plus an interfaith building in the Javanese style, and named after a Javanese prince, which references Indonesian tradition and mysticism, and offers place for all sorts of religious events, most notably purification ceremonies.

\section{Treasuries and libraries}

Most places of worship contain some sort of store. In some it may be a cupboard with a few old books and disused implements; in the Padmanabhaswamy Temple to Lord Vishnu in Trivandrum, Kerala, the treasures offered to the temple over thousands of years are still partly hidden in underground vaults and are said by some to be worth $\$ 700$ billion and to be guarded by cobras. Most 'treasuries' are of course more like the former than the latter, but in some countries the term 'religious museum' tends to mean church treasuries open to the public, of which the Treasury of St Mark's in Venice is perhaps the best known (Capurro, 2013; Gualdrini, 2013). In many great religious buildings traditional treasuries have merged into 'visitor centres', whose aim is to interpret to visitors the site, its architecture, history and underlying faith. These very often include displays of historic treasures alongside their interpretive exhibits, ticketing desks and the inevitable shop. Sometimes these treasuries grow into significant museums, as for example that of Kykkos Monastery on Cyprus, or the recently-opened Queen's Diamond Jubilee Galleries at Westminster Abbey in London.

Museums and libraries have worked closely together for generations. Libraries in places of worship, besides often being visitor attractions in their own right, are also frequently closely associated with treasury/museums. Winchester Cathedral in southern England is creating a new exhibition centre, and the highlight will be the Great Bible. This was commissioned in II6o, probably by Bishop Henry of Blois, grandson of William the Conqueror, who intended it to be kept on the High Altar and processed as part of the regular liturgy. While the text is the work of a single scribe on the skins of some 250 calves, six different illuminators worked on the brilliantly coloured and gilded pictorial initials that start each chapter. Many of the world's Bible Museums, though, derive not from the libraries of places of worship, but from libraries built up by people (like van Kampen, above) who combine religious devotion with bibliographic enthusiasm. Others, like Bible World in Bangalore, India, are created by missionary societies (Paine, in press). 


\section{Arguing against science}

A few visitor attractions - museums, theme parks and even zoos - are set up to promote minority religious beliefs - beliefs that may be considered by others to be highly unusual, absurd, or even dangerous. Examples are Vedic Science and Creationism. Vedic Science is the belief that the Hindu Vedas describe an ancient society far more advanced scientifically and in every other way than any found today. At the Swaminarayan sect's second and even larger temple/ theme park, Akshardham New Delhi, visitors are taken on a boat-ride through a series of dioramas ('Sanskruti Vihar', the Cultural Boat Ride), that show the idyllic life of Vedic India, where all was harmony and happiness, and where most scientific and technological discoveries (including space travel, democracy, embryology, plastic surgery and gravity) were discovered thousands of years ago. To non-believers that may seem harmless, but the boat-ride concludes with a paean to the future of humankind and of India - subtly elided with Swaminarayan Hinduism. 'When Indian culture has a past so beautiful, Why can't we create a future, more beautiful? Together, we can!' Such a belief of course plays into the cultural and identity politics of modern India.

Similar struggles over 'who we really are' are taking place in many parts of the world, perhaps partly in response to globalisation. Not least is this true of the United States, where Creationism has grown in Evangelical Christian circles. This is the belief, based on the first chapter of the Christian Bible, that the universe was created by God pretty much as it is today; Young-Earth Creationists believe that happened less that Io,ooo years ago, rather than 4.5 billion years. They reject entirely both the theory of evolution and the implications of modern geology. $38 \%$ of all Americans believe in some form of Creationism.

By far the biggest of the world's few Creationist museums is that opened in 2007 in Kentucky, USA, by the Creationist organisation Answers in Genesis. The Creation Museum is best known for its dramatic dioramas, especially for those showing human children playing with baby dinosaurs, and Adam and Eve in the Garden of Eden (Trollinger and Trollinger, 2016). In much of its display, though, the Creation Museum presents just like a modern museum, with collections of dinosaur fossils and insects in conventional showcases supported by text panels; the museum deliberately challenges science museums on their own ground. Very different is Answers in Genesis's second attraction, an hour's drive away (Bielo, 20r8). Ark Encounter also uses conventional museum techniques, but is much more firmly a theme park, comprising a wooden 'reconstruction' of Noah's Ark, $155 \mathrm{~m}$ long, $26 \mathrm{~m}$ wide, and $\mathrm{r} 6 \mathrm{~m}$ tall. The Ark, too, is intended to become the centrepoint of a theme park that will include a pre-Flood walled city, first-century CE village, Tower of Babel and a journey illustrating the parting of the Red Sea.

I. https://news.gallup.com/poll/2I0956/belief-creationist-view-humans-new-low.aspx (Accessed I5.I.2019). 
Some believers keen to promote their faith through a visitor attraction opt for a museum, some for another kind of attraction. A twenty-minute train ride from my home takes me to Portsmouth, where just outside the Historic Dockyard a nineteenth century bank building has been converted by another Creationist organisation into Genesis Expo. This is a considerably more modest museum than its Kentucky sister (8,ooo visitors a year compared to about one million) but its displays include some imaginative highlights, for example the large 'egg-timer' demonstrating how sedimentation works, or the '4, ooo years old' dinosaur fossils from the Gobi Desert. Also in southern England, six miles outside Bristol, is Noah's Ark Zoo Farm. This is a delightful rural zoo with an impressive number of animals, housed in seemingly generous spaces and imaginatively interpreted, and with a lively programme of public events. It retains, though, a local reputation as 'rather strange'. The zoo grew out of a dairy farm run by a devout Evangelical Christian; his autobiography (Bush, 20I2) describes how he built it up from farm open days, and tells of his struggles both with local planners and with opponents of zoos, Christianity and Creationism. For this is - or at least used to be - a Creationist zoo, and Bush's autobiography includes an appendix setting out the case for old-Earth Creationism. Today's visitor will find plenty to confirm that this is a Christian place, but little about Creationism - indeed virtually all there is is a rather obscure room, probably missed by many visitors, containing a model of Noah's Ark, and panels setting out the case for an Early Archaean cataclysm which might, it is suggested, have been Noah's Flood. Encouragingly, too, the zoo today seems to have completely rejected its founder's denial of global warming; the zoo is today promoted as The Green Zoo, information panels put heavy emphasis on conservation, and the panel on British Mammals mentions climate change along with habitat loss, non-native species and pollution as threats to their future.

\section{Interfaith: museums and others}

There is a handful of museums around the world that are devoted to 'world religions' or 'interfaith', seeing their mission as explaining the various religions of the world, and pointing up their commonalities (Orzech, 2019). They come from two directions. Museums like Chaitanya Jyoti (the Sai Baba museum at Puttaparthi in India) or the Museum of World Religions at Taipei, emerge from traditions that see their own faith as only one among many ways of accessing God or attaining Nirvana. Museums like the St Mungo Museum of Religious Art and Life in Glasgow, or the Musée des Religions du Monde at Nicolet, Quebec, are fundamentally intended to promote understanding between people of different faiths.

This pattern seems to be only partly mirrored in other visitor attractions. Bukit Kasih (Hill of Love) in North Sulawesi, Indonesia, has a mosque, a Catholic church, a Protestant church, a Buddhist monastery and a Hindu temple - though apparently none are actually used; the park's hot springs seem to be the greater attraction. The Guan Yin Inter-religious Park at Phetchaburi, Thailand, was 
founded in 1997 by the highly eccentric Suchart Kosolkitiwong. Its twenty-eight hectare site is divided into a Mahayana-Daoism area, Theravada Buddhism area, Monks area, Hinduism area and the Guan Yin statue area. Beside Guan Yin there are statues of Siva, Brahma, Maitreya Buddha, the Jade Emperor and other Daoist immortals, plus other goddesses and spirits.

Most often visitor attractions focused on the multifaith theme are comparatively small, and the initiative of rather eccentric individuals. Three examples come from Jersey in the Channel Islands, Southern California in the USA, and Northern Thailand. The Fantastic Tropical Gardens on Jersey was opened to the public in 1956 by Horace Bexon, described by the local newspaper as an explorer; it lasted until 198. The Gardens were essentially a combination of a religious theme-park and a garden of economic botany. There was a Hindu Garden with shrines to Siva, Surya, Vishnu, Bhumi and Kubera, a South American section with figures of the Aztec god Huehueteotl, Mayan throne and Aztec Calendar Stone, an Islam section containing a mosque, and a China section with shrines to Creation, the Buddha and the Moon (Paine, 2019, p. I3o).

The 'outsider artist' Leonard Knight created his very own sacred place in the Californian desert: a huge painted adobe structure he called Salvation Mountain. Knight included a 'museum' in the complex, displaying a variety of objects found and given, with 'God is Love' in big red letters on the roof. He saw the site as a sacred place, and lived a hermit's life there to promote his understanding of God's love as a challenge to all the values of industrial society (Patterson, 20r6). Something rather comparable was created beside the Mekong River near Nong Khai, in Thailand. This was a 'spiritual garden', begun in 1978 by Bunleua Sulilat, a relatively poor man, quite untrained, who 'had few resources besides time, mixed concrete, and found objects.' His vision was highly personal, including not only nine-metre-tall statues of the Buddha, but also fifteen-metre-long protective giant snakes, along with figures of foreign soldiers, mermaids, and Hindu gods like Śiva and Brahma (McDaniel, 2017, p. I22).

\section{Shared motives}

The private gardens and structures created by eccentric individuals may seem rather far from the theme of this issue, Museology and the Sacred. I argue, though, that the desire to help visitors to understand and to empathise with religion is common to many founders and curators of many different kinds of attraction, be they museums, libraries, theme parks or other venues. The methods may vary, but the motives are very similar.

One religious theme park with which museum curators might have sympathy is Museumpark Orientalis, outside Nijmegen in the Netherlands. This large park, set in 30 hectares of wooded landscape, contains a 'Roman town', Bedouin camp, Syrian farm, Arab village, Jordanian Jewish Village and so on. It was originally founded in I9II to help familiarise local Catholics with the Holy Land, and to add an attraction for pilgrims to an intended basilica. The basilica 
was never built, the area was devastated in the Second World War, and after the war interest in religion collapsed in the Netherlands. The park, though, survived, reinvented and focussed on helping a now multi-cultural and very secular country to understand Christianity, Judaism and Islam. The Museumpark puts a strong emphasis on education, and maintains a scholarly intent (van Laarhoven, 1992).

Apart from both wanting to help people to understand religions, what do museums have in common with other visitor attractions involved with religion? The principal answer must surely be: their visitors. Sadly this is exactly the area in which we have the least information. We know disappointingly little about visitors to religious visitor attractions, and especially about what attitudes and understanding they bring with them, and how they respond to what they see. Museum managers in particular, I suggest, have a responsibility to research and to publish this kind of information about their visitors.

Despite this lack of data, but guided by sociologists of religion, we can at least intuit the reasons behind the changes that are taking place (Davie, 2013; Micklethwait \& Wooldridge, 2009). In many parts of the world a whole new kind of visitor is evolving. As prosperity increases, and a new middle class grows, its members in many countries are not abandoning their religion, but looking for new ways to express it. One of those ways is to combine traditional practices in traditional (but brightened-up) places of worship, combined with leisure activities in venues copied from the entertainment industry. Hence in the West religion is taken into theme parks and other visitor attractions, while in the East new entertainments are added to temples, and in both new techniques are developed to present and interpret religion.

\section{References}

Berns, S. (2015). Sacred Entanglements: Studying Interactions Between Visitors, Objects and Religion in the Museum. University of Kent.

Bielo, J. (2018). Ark Encounter: the Making of a Creationist Theme Park. New York: NYU Press.

Buggeln, G., Plate, B. S., \& Paine, C. (Eds). (2017). Religion in Museums: Global and Multidisciplinary Perspectives. London: Bloomsbury.

Buggeln, G., \& Franco, B. (Eds.). (2018). Interpreting Religion at Museums and Historic Sites. American Association for State and Local History Interpreting History Series. Lanham: Rowman \& Littlefield.

Bush, A. (2012). From Cows to Tigers: Building Noah’s Ark. Bristol: Moatwell Press.

I. For examples of the occasional study of individual attractions and exhibitions, see Michel (1999), Howes (2007) and Berns (2015). And see also Shackley (200I). 
Capurro, R. (2013). Musei e Oggetti Religiosi: Arte, Sacro e Cultura Religiosa nel Museo. Milan: Vita e Pensiero.

Carlà-Uhink, F., Steinkruger, J.-E., \& Freitag, F. (Eds.). (in press). Key Concepts in Theme Park Studies.

Davie, G. (2013). The Sociology of Religion: a Critical Agenda. London: Sage.

Gualdrini, G. (2013). 'The Diocesan Museum: Artworks and Places.' In Valeria Minucciani (ed). Religion and Museums: Immaterial and Material Heritage. Turin: Umberto Allemandi.

Howes, G. (2007). The Art of the Sacred: an Introduction to the Aesthetics of Art and Belief. London: I. B. Tauris.

Hendry, J. (2000). The Orient Strikes Back: a Global View of Cultural Display. Oxford: Berg.

van Laarhoven, J. (20I4). Museumpark Orientalis, Nijmegen, Netherlands. Material Religion: the Journal of Objects, Art and Belief, Io, 2.

Mairesse, F. (2018). Museology and the Sacred. In F. Mairesse (Ed.), Museology and the Sacred: Materials for a Discussion. Paris: ICOFOM.

McDaniel, J. T. (2017). Architects of Buddhist Leisure: Socially Disengaged Buddhism in Asia's Museums, Monuments, and Amusement Parks. Honolulu: University of Hawai'i Press.

Michel, P. (1999). La Réligion au Musée: Croire dans l'Europe Contemporaine. Paris: Harmatan.

Micklethwait, J., \& Wooldridge, A. (2009). God is back: How the Global Rise of Faith is Changing the World. London: Allen Lane.

Orzech, C. (2019). Museums of World Religions: Displaying the Divine, Shaping Cultures. Bloomsbury Studies in Material Religion. London: Bloomsbury.

Paine, C. (2013). Religious Objects in Museums: Private Lives and Public Duties. London: Bloomsbury.

Paine, C. (2019). Gods and Rollercoasters: Religion in Theme Parks Worldwide. London: Bloomsbury.

Paine, C. (in press). 'Bible Museums'. In J.S. Bielo \& L. Wijnia (Eds.), The Bible and Global Tourism. London: Bloomsbury.

Patterson, S. M. (2016). Middle of Nowhere: Religion, Art, and Pop Culture at Salvation Mountain. Albuquerque: University of New Mexico Press.

Shackley, M. (200I). Managing Sacred Sites: Service Provision and Visitor Experience. London: Continuum.

Shaw, J. (20II). Octavia Daughter of God: the Story of a Female Messiah and her Followers. London: Jonathan Cape. 
Trollinger, S. L., \& Trollinger, W. V., Jr. (2016). Righting America at the Creation Museum. Baltimore: Johns Hopkins University Press. 